\title{
Determinants of investment in fixed assets and in intangible assets for high- tech firms
}

\section{Paulo Maçãs Nunes}

Management and Economics Department, Beira Interior University

and CEFAGE Research Centre

Portugal

\section{Zélia Serrasqueiro}

Management and Economics Department, Beira Interior University and CEFAGE Research Centre

Portugal

zelia@ubi.pt

\section{António Fernandes de Matos}

Management and Economics Department, Beira Interior University

Portugal

fmatos@ubi.pt

Abstract. Based on a sample of 141 Portuguese high-tech firms for the period 20042012 and using GMM system (1998) and LSDVC (2005) dynamic estimators, this paper studies whether the determinants of high-tech firms' investment in fixed assets are identical to the determinants of their investment in intangible assets. The multiple empirical evidence obtained allows us to conclude that the determinants of their investment in fixed assets are considerably different from those of their investment in intangible assets. Debt is a determinant stimulating investment in fixed assets, with age being a determinant restricting such investment. Size, age, internal finance and GDP are determinants stimulating investment in intangible assets, whereas debt and interest rates restrict such investment. These results let us make important suggestions for the owners/managers of high-tech firms, and also for policy-makers.

Keywords: investment in fixed assets, investment in intangible assets, KIBS, panel data.

JEL Classification: C23, G32, L26
Received: October, 2016 1st Revision: February, 2017 Accepted: April, 2017

DOI: $10.14254 / 2071-$ $8330.2017 / 10-1 / 12$ 


\section{INTRODUCTION}

According to Máñez et al. (2015), a significant number of the European Union policies aim to encourage firms increase their innovation activities, so as to improve their productivity. In this context, the new European long-term research policy strategy "Horizon 2020" is especially relevant, and Najjar et al. (2013) and Muscettola (2015) state that firms' innovation is a determinant of countries' economic growth.

Audretsch (1995), Henrekson \& Johansson (2010) and Colombo et al. (2014) say that high-tech firms are very important for developed countries as the drivers of their economic growth and employment. In the context of high-tech firms' activities, intangible assets are of great importance (Dilling-Hansen \& Smith, 2014; Hussinger \& Pacher, 2015). However, the great weight of intangible assets and lesser weight of fixed assets, which characterizes high-tech firms compared to firms in other sectors, could contribute decisively to high-tech firms finding it difficult to access external finance, when internal funds are clearly insufficient (Coleman \& Robb, 2009).

Considering the importance of high-tech firms for economic growth and employment particularly in developed countries, and also considering that these firms' activity is characterized by a significant variety of fixed and intangible assets, this paper is the first to study the differences in the determinants of investment in fixed assets and intangible assets in high-tech firms. Methodologically, we use the sample of 141 Portuguese high-tech firms, for the period 2004-2012, and using the GMM system (1998) and LSDVC (2005) dynamic estimators as estimation methods.

The evidence obtained in this paper allows us conclude there are significant differences between the determinants of investment in fixed assets and in intangible assets in high-tech firms.

After this introduction, the paper is structured as follows: i) Section II presents the methodology used, namely the database, variables and estimation methods; ii) Section III presents the results of the paper; and iii) Section IV presents the conclusions and implications.

\section{METHODOLOGY}

\subsection{Database}

This study uses the SABI (Analysis System of Iberian Balance Sheets) database from Bureau van Dijks for the period 2004-2012.

As our subject of analysis is high-tech firms we select high-tech firms according to ISIC Rev.3. The sub-sectors of high-tech firms are: 2423 Pharmaceuticals; 30 Office, Accounting and Computing Machinery; 32 Radio, TV and Communication Equipment; 33 Medical, Precision and Optical Instruments; 353 Aircraft and Spacecraft. So as to avoid bias in the estimated results and simultaneously have a more representative sample of the situation of high-tech firms in Portugal, we consider the following types of high-tech firms: i) those that are in the market for the whole period of analysis (2004-2012); ii) those entering the market during the period of analysis (2004-2012) and; iii) those leaving the market during the period of analysis (2004-2012).

Arellano and Bond (1991) conclude that when using dynamic panel estimators, it is necessary for units of analysis to be included in the database for at least four consecutive years, otherwise they cannot be considered in the second order autocorrelation tests which are fundamental to validate the results obtained using dynamic panel estimators. Therefore, we only include in the sample high-tech firms which are present for at least four consecutive years. 
Based on the criteria presented, the sample of high-tech firms considered in this study is made up as follows: i) 87 high-tech firms present in the market for the whole period of analysis (2004-2012); ii) 33 hightech firms entering the market during the period of analysis (2004-2012) and iii) 21 high-tech firms leaving the market during the period of analysis (2004-2012). The final sample is composed of 141 high-tech firms.

\subsection{Variables}

As dependent variables we consider investment in fixed assets and investment in intangible assets. The independent variables are: i) size; ii) age; iii) cash flow; iv) debt; v) GDP; and vi) interest rate.

The following table presents the variables used in this study together with their corresponding measures.

Table 1

Variables and Measurement

\begin{tabular}{|c|c|}
\hline Variables & Measurement \\
\hline \multicolumn{2}{|l|}{ Dependent Variable } \\
\hline $\begin{array}{l}\text { Investment in Fixed Assets } \\
\left(\text { INVFA }_{i, t}\right)\end{array}$ & Percentage of change of growth in fixed assets \\
\hline $\begin{array}{l}\text { Investment in Intangible Assets } \\
\left.\text { (INVITA }_{i, t}\right)\end{array}$ & Percentage of change of growth in intangible assets \\
\hline \multicolumn{2}{|l|}{ Independent Variables } \\
\hline Size $\left(\mathrm{SIZE}_{\mathrm{i}, \mathrm{t}-1}\right)$ & Logarithm of Sales \\
\hline Age $\left(\mathrm{AGE}_{\mathrm{i}, \mathrm{t}-1}\right)$ & Logarithm of number of existence firm years \\
\hline Cash Flow $\left(\mathrm{CF}_{\mathrm{i}, \mathrm{t}-\mathrm{1}}\right)$ & $\begin{array}{l}\text { Ratio between operational results before tax and interests plus } \\
\text { amortizations and total assets }\end{array}$ \\
\hline Debt $\left(\mathrm{LEV}_{\mathrm{i}, \mathrm{t}}\right)$ & Ratio between debt and total assets \\
\hline Gross Domestic Product $\left(\mathrm{GDP}_{\mathrm{t}}\right)$ & Logarithm of Gross Domestic Product Per capita \\
\hline Interest Rates $\left(\mathrm{IR}_{\mathrm{t}}\right)$ & Market interest rate, corresponding to the 3 month Euribor rate \\
\hline
\end{tabular}

\subsection{Estimation Methods}

The regressions to estimate can be represented as follows:

$$
\begin{aligned}
& \operatorname{INVFA}_{i, t}=\beta_{0}+\delta \operatorname{INVFA}_{i, t-1}+\beta_{1} \operatorname{SIZE}_{i, t-1}+\beta_{2} A G E_{i, t-1}+\beta_{3} C F_{i, t-1}+ \\
& +\beta_{4} \mathrm{LEV}_{i, t-1}+\beta_{5} \operatorname{SDP}_{t-1}+\beta_{6} I_{t-1}+u_{i}+\eta d_{t}+e_{i, t} \\
& \operatorname{INVITA}_{i, t}=\beta_{0}+\delta \operatorname{INVITA}_{i, t-1}+\beta_{1} S I Z E_{i, t-1}+\beta_{2} A G E_{i, t-1}+\beta_{3} C F_{i, t-1}+ \\
& +\beta_{4} \text { LEV }_{i, t-1}+\beta_{5} \operatorname{GDP}_{t-1}+\beta_{6} I_{t-1}+u_{i}+\eta d_{t}+e_{i, t}
\end{aligned}
$$

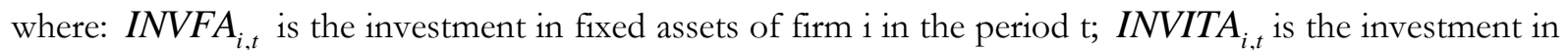
intangible assets of firm $\mathrm{i}$ in period t; INVFA $A_{i, t-1}$ is the investment in fixed assets of firm $\mathrm{i}$ in period t-1; $\operatorname{INVITA}_{i, t-1}$ is the investment in intangible assets of firm $\mathrm{i}$ in period $\mathrm{t}-1 ; S I Z E_{i, t-1}$ is the size of firm $\mathrm{i}$ in period $\mathrm{t}-1 ; A G E_{i, t-1}$ is the age of firm $\mathrm{i}$ in period $\mathrm{t}-1 ; C F_{i, t-1}$ is the cash flow of firm $\mathrm{i}$ in the period $\mathrm{t}-1$; $L E V_{i, t-1}$ is the debt of firm $\mathrm{i}$ in the period t-1;GDP $P_{t-1}$ is gross domestic product in the period t-1; IR is the interest rate in period $\mathrm{t}-1 ; u_{i}$ are effects that are non-observable through the independent variables; 
$d_{t_{t}}$ are annual dummy variables measuring time effects not measured by GDP and interest rates; and $e_{i, t}$ is the error, which is assumed to have normal distribution.

Aiming to estimate regressions (1) and (2) we use dynamic panel estimators. Using dynamic panel estimators has the following advantages over traditional methods of panel data regressions (i.e. OLS regressions, regressions admitting the existence of random effects, regressions admitting the existence of fixed effects): i) high control of endogeneity; ii) greater control of possible collinearity between independent variables; iii) more effective control of the effects of the possible absence of independent variables relevant in explaining the dependent variable.

Blundell \& Bond (1998) state that when the dependent variable is persistent (i.e. when high correlation is found between the dependent variable in the current period and the dependent variable in the previous period), the results obtained with the GMM (1991) estimator may not be robust. We calculate the correlation coefficients between investment in fixed assets in the current and previous periods, obtaining a correlation coefficient of 0.5928 , and between investment in intangible assets in the current and previous periods, obtaining a correlation coefficient of 0.5143 . Therefore, considering the persistence of the investment, it is more suitable to use the GMM system (1998) estimator than the GMM (1991) estimator.

Two conditions are necessary for the results obtained with the GMM system (1998) estimator to be considered robust. Firstly, the restrictions created by the instruments used must be valid. Secondly, there can be no autocorrelation of second order errors. To test the validity of the restrictions created by use of the instruments, we use the Hansen test. The null hypothesis is validity of the restrictions, as a consequence of the instruments used, with the alternative hypothesis being non-validity of the restrictions.

We also test for the existence of autocorrelation of first and second order errors. The null hypotheses indicate non-existence of error autocorrelation, with the alternative hypotheses indicating the existence of error autocorrelation. If we do not reject the null hypotheses of validity of restrictions, as a consequence of the instruments used, and absence of second order autocorrelation, the results obtained with the GMM system (1998) estimator can be considered robust and consequently open to interpretation. Otherwise, the results obtained with the GMM system (1998) dynamic estimator cannot be considered robust and are consequently not open to interpretation.

Bruno (2005) concludes that when samples have a number of cross-sections under 30, and consequently the number of observations is quite low, results obtained with the GMM system (1998) estimator may suffer from some bias. When the number of observations in not very high, Bruno (2005) proposes a dynamic fixed effect estimator, namely the LSDVC (Least Squares Dummy Variable Corrected) estimator. As in this paper, the number of cross-sections is under 30 and the number of observations is not very high, we use the LSDVC (2005) estimator to test the robustness of the results obtained with the GMM system (1998) estimator.

Based on the above, aiming to estimate the regressions expressed by equations (1) and (2) we resort to the GMM system (1998) and LSDVC (2005) dynamic estimators.

\section{RESULTS}

\subsection{Descriptive Statistics and Correlation Matrix}

Table 2 presents the descriptive statistics of the variables used in the paper together with their correlations. 
Descriptive Statistics and Correlation Matrix

\begin{tabular}{|c|c|c|c|c|c|c|c|c|c|c|}
\hline & Mean & S.D. & (1) & (2) & (3) & (4) & (5) & (6) & (7) & (8) \\
\hline (1) INVFA $_{i, t}$ & 0.07182 & 0.30912 & 1 & & & & & & & \\
\hline (2) INVITA & 0.08019 & \begin{tabular}{|l|}
0.34519 \\
\end{tabular} & $0.05^{* *}$ & 1 & & & & & & \\
\hline (3) SIZE $_{i, t}$ & 12.1891 & 1.34159 & $0.27 * *$ & $0.08^{* *}$ & 1 & & & & & \\
\hline (4) $A G E_{i, t}$ & 2.79120 & 0.81729 & $0.12^{* *}$ & $0.06^{* *}$ & $0.19^{* *}$ & 1 & & & & \\
\hline (5) $\mathrm{CF}_{\mathrm{i}, \mathrm{t}}$ & 0.08192 & 0.18283 & -0.01 & $0.37 * *$ & $0.18^{* *}$ & $0.08^{* *}$ & 1 & & & \\
\hline (6) $L E V_{i, t}$ & 0.62830 & 0.19820 & $-0.03^{*}$ & $-0.16^{* *}$ & $0.05^{* *}$ & 0.02 & $-0.35 * *$ & 1 & & \\
\hline (7) $\mathrm{GDP}_{\mathrm{t}}$ & 9.77433 & \begin{tabular}{|l|l|l|l|l|}
0.1014 \\
\end{tabular} & $0.21^{* *}$ & $0.22^{* *}$ & $0.11^{* *}$ & -0.02 & $0.10^{* *}$ & $-0.03^{*}$ & 1 & \\
\hline (8) $\mathrm{IR}_{\mathrm{t}}$ & 2.26574 & 1.45938 & $-0.09 *$ & $-0.17 *$ & $-0.03^{*}$ & $-0.06 * *$ & $-0.04 * *$ & $-0.05 * *$ & $0.06^{*}$ & 1 \\
\hline
\end{tabular}

Notes: $1 .{ }^{* *}$ statistical significant at $1 \%$ level; * statistical significant at $5 \%$ level.

We can state that investment in fixed assets is quite similar to investment in intangible assets. In addition, we find that the variables of: i) investment in fixed assets, investment in intangible assets and cash flow are considerably volatile, since the standard deviations of the variables are above the respective means; and ii) size, age, debt, Gross Domestic Product and interest rate are not very volatile, as the standard deviations of the variables are under the respective means.

Gujarati and Porter (2010) state that when the correlation coefficients between independent variables are under $50 \%$, problems of collinearity between independent variables are not particularly relevant. All the correlation coefficients between independent variables are found to be under $50 \%$, and so problems of collinearity between independent variables will not be relevant in this study.

\subsection{Regressions}

Table 3 presents the regressions referring to the determinants of investment in fixed assets ${ }^{1}$ and determinants of investment in intangible assets, considering the GMM system (1998) and LSDVC (2005) dynamic estimators as methods.

Whether considering investment in fixed assets or investment in intangible assets, the results of the Hansen test let us conclude we cannot reject the null hypothesis of validity of the instruments used. Furthermore, also whether considering investment in fixed assets or in intangible assets, the results of the second order autocorrelation tests indicate we cannot reject the null hypothesis of absence of second order autocorrelation. Based on the Hansen and second order autocorrelation tests, we find that irrespective of considering investment in fixed assets or investment in intangible assets, the results are robust and consequently open to interpretation.

Concerning the determinants of investment in fixed assets and those of investment in intangible assets, the results obtained with the LSDVC (2005) dynamic estimator are almost identical to those obtained with the GMM system (1998) dynamic estimator, confirming the empirical evidence obtained here.

The multiple empirical evidence obtained allows us to conclude that: i) debt is a determinant stimulating investment in fixed assets; ii) age is a determinant restricting investment in fixed assets; iii) size, age and cash flow are determinants stimulating investment in intangible assets; and iv) debt and the interest rate are

1 Alternatively, just as Colombo et al. (2014), we estimate the determinants of investment in fixed assets using the error correction model (ECM). The results are similar to those presented in Table 3 and can be requested from the authors. 
determinants restricting investment in intangible assets. In addition, positive relationships are found between investment in the current period and investment in the previous period, irrespective of focusing on investment in fixed assets or in intangible assets, revealing that investment in fixed and intangible assets is persistent over time.

Table 3

Investment Determinants

\begin{tabular}{|c|c|c|c|c|}
\hline & \multicolumn{2}{|c|}{ 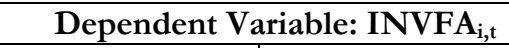 } & \multicolumn{2}{|c|}{ 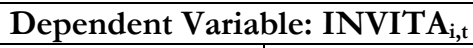 } \\
\hline $\begin{array}{c}\text { Independent } \\
\text { Variables }\end{array}$ & $\begin{array}{c}\text { GMM system } \\
\text { (1998) }\end{array}$ & $\begin{array}{l}\text { LSDVC } \\
(2005)\end{array}$ & $\begin{array}{c}\text { GMM system } \\
\text { (1998) }\end{array}$ & $\begin{array}{l}\text { LSDVC } \\
(2005)\end{array}$ \\
\hline INVFA $_{i, t-1}$ & $\begin{array}{c}0.31371^{* *} \\
(0.03919)\end{array}$ & $\begin{array}{c}0.30192 * * \\
(0.06089)\end{array}$ & & \\
\hline INVIt $_{i, t-1}$ & & & $\begin{array}{c}0.10293 * * \\
(0.02394)\end{array}$ & $\begin{array}{c}0.13818^{* *} \\
(0.03127)\end{array}$ \\
\hline $\mathrm{SIZE}_{\mathrm{i}, \mathrm{t}-1}$ & $\begin{array}{c}0.08281 \\
(0.17819)\end{array}$ & $\begin{array}{c}0.09109 \\
(0.18172)\end{array}$ & $\begin{array}{c}0.12837^{* *} \\
(0.02129)\end{array}$ & $\begin{array}{c}0.13464^{* *} \\
(0.02561)\end{array}$ \\
\hline $\mathrm{AGE}_{\mathrm{i}, \mathrm{t}-1}$ & $\begin{array}{c}-0.12362 * \\
(0.06087)\end{array}$ & $\begin{array}{c}-0.14637 * * \\
(0.04298)\end{array}$ & $\begin{array}{c}0.30156^{* *} \\
(0.10015)\end{array}$ & $\begin{array}{l}0.32526^{*} \\
(0.16018)\end{array}$ \\
\hline $\mathrm{CF}_{\mathrm{i}, \mathrm{t} .1}$ & $\begin{array}{c}0.12992 \\
(0.71729) \\
\end{array}$ & $\begin{array}{c}0.13481 \\
(0.75160) \\
\end{array}$ & $\begin{array}{c}0.61821 * * \\
(0.19231) \\
\end{array}$ & $\begin{array}{r}0.58482^{* *} \\
(0.20112) \\
\end{array}$ \\
\hline $\mathrm{LEV}_{\mathrm{i}, \mathrm{t} .1}$ & $\begin{array}{c}0.51622 * * \\
(0.12939) \\
\end{array}$ & $\begin{array}{c}0.52728^{* *} \\
(0.13556)\end{array}$ & $\begin{array}{c}-0.20918^{*} \\
(0.10243) \\
\end{array}$ & $\begin{array}{c}-0.22010^{* *} \\
(0.10718) \\
\end{array}$ \\
\hline $\mathrm{GDP}_{\mathrm{t}-1}$ & $\begin{array}{c}0.01828 \\
(0.12 \mathrm{I} 30)\end{array}$ & $\begin{array}{l}-0.08192 \\
(0.44517)\end{array}$ & $\begin{array}{c}0.23647^{* *} \\
(0.05678)\end{array}$ & $\begin{array}{c}0.20182^{* *} \\
(0.04125)\end{array}$ \\
\hline $\mathrm{IR}_{\mathrm{t}-1}$ & $\begin{array}{c}0.06112 \\
(0.22736) \\
\end{array}$ & $\begin{array}{c}0.11928 \\
(0.69192) \\
\end{array}$ & $\begin{array}{l}-0.21374 \\
(0.06132) \\
\end{array}$ & $\begin{array}{c}-0.27182^{* *} \\
(0.08194) \\
\end{array}$ \\
\hline CONS & $\begin{array}{c}0.04132 * * \\
(0.01192)\end{array}$ & $\begin{array}{c}0.04019 * * \\
(0.01034)\end{array}$ & $\begin{array}{l}-0.09341 \\
(0.21029)\end{array}$ & $\begin{array}{l}-0.10561 \\
(0.22901)\end{array}$ \\
\hline Hansen $\left(\chi^{2}\right)$ & 32.90 & 30.91 & 40.10 & 41.12 \\
\hline $\mathrm{m}_{1}(\mathrm{~N}(0.1))$ & $-6.18^{* *}$ & $-6.62 * *$ & $-4.39 * *$ & $-4.14 * *$ \\
\hline $\mathrm{m}_{2}(\mathrm{~N}((0.1))$ & 0.31 & 0.38 & 0.12 & 0.18 \\
\hline Firms & 181 & 181 & 181 & 181 \\
\hline Observations & 1401 & 1401 & 1401 & 1401 \\
\hline
\end{tabular}

Notes: 1. Standard deviations in parenthesis. 2. ** significant at $1 \%$ level; * significant at $5 \%$ level. 3 . The regressions include time dummy variables but are not shown.

\section{CONCLUSIONS AND IMPLICATIONS}

Based on a sample of 141 high-tech firms for the period 2004-2012 and using the GMM system (1998) and LSDVC (2005) dynamic estimators, this paper studies the determinants of investment in fixed assets and in intangible assets.

The paper makes an important contribution to the literature on high-tech firms' investment, since it is pioneering in comparing the determinants of investment in fixed assets and that in intangible assets. The multiple empirical evidence obtained reveals that the determinants of investment in fixed assets are quite different from those of investment in intangible assets. Firstly, debt is a determinant stimulating investment in fixed assets, with age restricting investment in fixed assets. Secondly, size, age, cash flow and GDP stimulate investment in intangible assets, while debt and interest rates restrict such investment. Furthermore, investment in fixed assets and investment in intangible assets are found to be persistent, with that persistence being greater in the case of investment in fixed assets. 
The empirical evidence obtained in this paper lets us make important suggestions for policy-makers and for the owners/managers of high-tech firms. For the former: i) given the importance of intangible assets for high-tech firms, and considering that internal finance is a determinant stimulating investment in this type of asset, with debt being a restrictive determinant, we suggest creating specific lines of credit to support investment in intangible assets when internal financing is clearly insufficient for the purpose; ii) considering that investment in intangible assets is very sensitive to changes in the economic situation, increasing as a function of GDP and diminishing as a function of interest rates, we suggest creating specific programmes to support the activity of high-tech firms in periods of recession characterized by falling GDP and increased interest rates; and iii) given that greater size and age are determinants stimulating investment in intangible assets, we suggest providing specific support for small and young high-tech firms with insufficient internal finance to take advantage of all their good investment opportunities through increasing their intangible assets. For the owners/managers of high-tech firms: i) we suggest forming trusting relationships with creditors so that when internal finance is insufficient, high-tech SMEs can turn to debt on advantageous terms to finance their investment in intangible assets, these trusting relationships being all the more important, the smaller and younger the high-tech firm; and ii) considering that high-tech firms finance their investment in fixed assets through debt, with internal funding apparently not being relevant for the purpose, we suggest a trade-off is found between internal finance and debt, so that situations of excessive debt do not contribute to considerable stress in managing financial resources, due to paying high charges on the debt contracted, which could mean not making efficient use of good investment opportunities in the future.

\section{REFERENCES}

Al-Najjar, B., \& Elgammal, M. M. (2013). Innovation and credit ratings, does it matter? UK evidence. Applied Economics Letters, 20(5), 428-431.

Arellano, M., \& Bond, S. (1991). Some tests of specification for panel data: Monte Carlo evidence and an application to employment equations. The review of economic studies, 58(2), 277-297.

Audretsch, D. B. (1995). Innovation and industry evolution. Mit Press.

Blundell, R., \& Bond, S. (1998). Initial conditions and moment restrictions in dynamic panel data models. Journal of econometrics, 87(1), 115-143.

Bruno, G. S. (2005). Approximating the bias of the LSDV estimator for dynamic unbalanced panel data models. Economics Letters, 87(3), 361-366.

Coleman, S., \& Robb, A. (2009). A comparison of new firm financing by gender: evidence from the Kauffman Firm Survey data. Small Business Economics, 33(4), 397-411.

Colombo, M. G., Croce, A., \& Guerini, M. (2014). Does informal risk capital relax the financial constraints of hightech entrepreneurial ventures?. Applied Economics Letters, 21(5), 335-339.

Dilling-Hansen, M., \& Smith, V. (2014). R\&D, export and productivity: testing the Bustos model on Danish data. Applied Economics Letters, 21(11), 733-737.

Gujarati, D. N., \& Porter, D. C. (2010). Essentials of Econometrics. 4th ed. New York`: McGraw - Hill International.

Henrekson, M., \& Johansson, D. (2010). Gazelles as job creators: a survey and interpretation of the evidence. Small Business Economics, 35(2), 227-244.

Hussinger, K. \& Pacher, S. (2015). Information Ambiguity and Firm Value. Applied Economics Letters, 22, 843-847.

Máñez, J. A., Rochina-Barrachina, M. E., Sanchis-Llopis, A., \& Sanchis-Llopis, J. A. (2015). The determinants of R\&D persistence in SMEs. Small Business Economics, 44(3), 505-528.

Muscettola, M. (2015). Difficulties for small firms to invest in research prerogatives. An empirical analysis of a sample of Italian firms. Applied Economics, 47(15), 1495-1510. 